\title{
OTONOMI KHUSUS DAN KEMISKINAN DI ACEH: Gambaran Kemiskinan Pelaku Usaha Batu Bata di Desa Ulee Pulo Kecamatan Dewantara Kabupaten Aceh Utara
}

\author{
Teuku Alfiady ${ }^{1)}$ \& Risna Dewi ${ }^{2)}$ \\ ${ }^{1)}$ Program Studi Administrasi Publik Universitas Malikussaleh \\ email: afliady@unimal.ac.id \\ ${ }^{2)}$ Program Studi Administrasi Publik Universitas Malikussaleh \\ email: risna.dewi@unimal.ac.id
}

\begin{abstract}
ABSTRAK
Dalam rangka pengentasan kemiskinan. Besarnya jumlah dana yang dikucurkan melalui dana otonomi khusus tidak secara otomatis memberikan solusi atas kemiskinan yang sebenarnya sebagai sumber disintegrasi pada masa itu. Kegagalan pemanfaatan dana otsus terlihat jelas dari posisi Aceh sebagai sepuluh daerah termiskin di Indonesia dengan jumlah masyarakat miskin sebanyak 839 ribujiwa atau 15,97 persen pada tahun 2018. Lebih buruknya kemiskinan justru tidak menurun, dimana kemiskinan justru semakin meningkat. Pada tahun 2017 masyarakat miskin di Aceh 829 ribu jiwa atau naik 10 ribu jiwa pada tahun selanjutnya. Ini merupakan fakta empirik yang memperlihatkan adanya kesalahan dalam tata kelola keuangan. Melimpahnya kekayaan dan kucuran uang ternyata tidak semana-mena menjadikan Aceh lebih baik. Penelitian ini mencoba untuk menjelaskan fenomena di atas. Dengan mememahmi realita kemiskinan yang dihadapi oleh masyarakat sebagai buruh pada usaha-usaha pembuatan batu bata di Desa Ulee Pulo Kecamatan Dewantara Kabupaten Aceh Utara. Mereka bekerja tanpa ada jaminan sosial dan upah yang layak, sedangkan pekerjaan yang dijalani berhadapan dengan resiko yang besar. Secara praktis pemberian otonomi khusus dapat menanggulangani persoalan disintegrasi, namun otonomi khusus belum dapat menjawab persoalan yang substansial yaitu penanganan kemiskinan secara absulot. Penelilitian ini menggunakan pendekatan kulaitatif deskriptif dimana informasi digali secara mendalam mungkin dari sumber yang kredibel dan relevan yang dapat menjawab persoalan yang diajukan.
\end{abstract}

Kata Kunci: Otonomi Khusus, pengentasan kemiskinan dan pelaku usaha batu bata

\section{PENDAHULUAN}

Dana Otonomi Khusus (otsus) adalah sebuah anugerah bagi Aceh dalam upaya untuk bangkit dari keterpurukan ekonomi yang telah berlangsung berkepanjangan. Kemiskinan yang berlangsung di Aceh hingga saat ini menjadi perhatian masyarakatnya. Betapa tidak banyaknya dana otsus yang dikucurkan 
oleh pemerintah pusat (RI) melalui dana Otsus dengan angka yang pantastis ternyata tidak memberikan perubahan yang sangat fundamental bagi kesejahteraan masyarakatnya. Sebaliknya, dana yang besar tersebut justru menghadirkan permasalahan baru bagi pembangunan Aceh yaitu ketimpangan pembangunan. Besarnya anggaran yang dimiliki ternyata tidak sejalan dengan reformasi pembangunan yang mengarah pada pengetasan kemiskinan.

Dana otsus yang diharapkan sebagai obat mujarab dalam memberikan kesembuhan penyakit untuk warga "miskin" akibat konflik senjata dan sosial yang berkepanjangan ternyata hanya mampu mensejahterakan masyarakat Aceh secara sepihak. Faktanya pada tahun 2018 angka kemiskinan di Aceh mencapai 839 ribu jiwa (15,97 persen) dan masuk ke dalam 10 daerah termiskin di Indonesia pada Maret 2018. Jumlah penduduk miskin pada tahun tersebut meningkat ketimbang tahun sebelumnya (2017) sebanyak 10 ribu jiwa dari 829 ribu jiwa (15,92 persen). Besarnya angka kemiskinan tersebut tidak sejalan dengan besarnya dana otsus yang mencapai 8,03 Tiriliun rupiah pada tahun 2018 dan 2017.

Dana otsus merupakan kompensasi pemerintah RI terhadap pemerintah Aceh atas kesepakatan damai yang dicapai Undang-Undang Nomor 11 tahun 2006 tentang Pemerintah Aceh dengan alokasi dana otonomi khusus. tahun 2008 adalah sebesar Rp 3,59 Triliun dan terus meningkat setiap tahunnya sesuai perkembangan DAU Nasional. Total dana otsus yang sudah diterima Aceh sampai tahun 2018 adalah sebesar Rp 56,67 Triliun. Jumlah dana otsus yang sudah diterima merupakan jumlah yang sangat besar untuk bisa dimanfaatkan untuk pembangunan guna meningkatkan kesejahteraan masyarakat Aceh. Dalam rangka pengentasan kemiskinan. Hal ini sesuai pernyataan Gubernur Aceh:

Tabel 1: Dana Otonomi Khusus Dari Tahun 2008-2018

\begin{tabular}{|l|l|l|}
\hline No & $\begin{array}{c}\text { Tahun } \\
\text { Anggran }\end{array}$ & $\begin{array}{c}\text { Jumlah Dana } \\
\text { Rp }\end{array}$ \\
\hline 1 & 2008 & 3,5 triliun \\
2 & 2009 & 3,7 triliun \\
3 & 2010 & 3,8 triliun \\
4 & 2011 & 4,5 triliun \\
5 & 2012 & 5,4 triliun \\
6 & 2013 & 6,1 triliun \\
7 & 2014 & 8,1 triliun \\
\hline
\end{tabular}

39 


\begin{tabular}{|l|l|l|}
\hline 8 & 2015 & 7,0 triliun \\
9 & 2016 & 7,7 triliun \\
10 & 2017 & 8,0 triliun \\
11 & 2018 & 8,03 triliun \\
\hline
\end{tabular}

(Sumber: Bappeda Aceh)

Fakta di atas menyajikan satu pertanyaan penting apakah kekayaan menjadi satu-satunya faktor dalam mengetaskan persoalan kemiskinan? pada kenyataannya, faktor politik adalah faktor yang paling dominan memainkan peranan bagi munculnya penduduk miskin baru akibat berbagai kebijakan yang dibuat. Selain itu, faktor pendidikan yang rendah, dan faktor infrastruktur yang terbatas menjadi penyebab makin banyaknya kemiskinan di Indonesia. Meskipun memiliki sumber daya alam yang berlimpah namun apabila hidup di daerah yang tertinggal dengan infrastruktur yang terbatas maka besar kemungkinan individu tersebut akan tetap terjebak dalam lingkaran kemiskinan.

Otonomi khusus Aceh dipandang dapat mengurangi kemiskinan dengan lebih cepat apabila didorong oleh tata kelola pemeritahan yang baik. Otonomi khusus di Aceh akan meningkatkan efesiensi alokasi sumberdaya karena pemerintah di daerah lebih dekat dengan warga daripada pemerintah pusat sehingga pemerintah di daerah diharapkan memiliki informasi yang akurat dan bisa menyelesaikan persoalan dengan lebih cepat.

Ketidak merataan distribusi dana ini tampak jelas jika melihat kehidupan masyarakat di Desa Ulee Pulo Kecamatan Dewantara Kabupaten Aceh Utara yang belum tersejahterakan secara utuh. Ulee Pulo salah satu desa sebagai penghasil batu bata terbesar di Aceh Utara, hampir seluruh warganya bekerja pada sektor tersebut baik sebagai pemilik maupun sebagai buruh. Baik bekerja pada pembuat dasar, pembakar, maupun pengangkut batu bata. Ketergantungan mereka terhadap sektor ini pada satu sisi menjadi nilai tambah bagi perekonomian keluarga, akan tetapi di sisi yang lain sektor ini sangat riskan akan ancaman kegagalan terutama ketidak pastian pasar serta penyertaan modal kerja yang tidak pernah difikirkan oleh negara 
Ketika musim sepi pemesanan terkadang mereka menjual batu bata jadi di bawah harga standar (hanya cukup untuk biaya operasional modal dasar) perbutirnya. Banyak diantara pelaku usaha ini mengalami kebangkrutan sehingga tidak lagi mampu memproduksi batu bata lainnya. minimnya pendapatan ini berujung pada penyertaan modal yang didapatkan dengan cara hutang di Bank maupun pada individu dengan sistem "raintenir" dengan bunga yang besar. Pelaku usaha ini harus menyisihkan dari sebagian pendapatan yang mereka dapatkan untuk cicilan hutang.

\section{LANDASAN TEORI}

Batasan mengenai konsep desentralisasi dikemukakan oleh banyak ahli pemerintahan. Perbedaan sudut pandang para ahli mengakibatkan batasan yang pasti mengenai konsep desentralisasi sulit diperoleh. Perserikatan Bangsa-Bangsa sebagaimana dikutip oleh Koswara (2005) memberikan batasan bahwa desentralisasi adalah :

Decentralization refers to the transfer of authority away from the national capital wheter by deconcentration (i.e. delegation) to field office or by devolution to local authorities or local bodies.

Dari definisi tersebut menjelaskan bahwa terdapat proses penyerahan (transfer) kekuasaan dari pemerintah pusat (the national capital) dengan dua variasi yaitu (1) melalui dekonsentrasi (delegasi) kepada pejabat instansi vertikal di daerah atau (2) melalui devolusi (pengalihan tanggung jawab) kekuasaan pada pemeritaha yang memiliki otoritas pada daerah tertentu atau lembaga-lembaga otonom di daerah.

Definisi lainnya yang terdapat dalam Hand Book of Public Administration yang diterbitkan PBB mendefinisikan desentralisasi sebagai proses penyerahan kekuasaan pemerintah berikut fungsi-fungsinya yang dibedakan menjadi (1) dekonsentrasi yaitu kekuasaan dan fungsi pemerintahan diberikan secara administratif kepada instansi vertikal pemerintah pusat yang ada di daerah dan (2) devolusi yaitu kekuasaan dan fungsi pemerintahan diberikan kepada pemerintah 
loka yang memiliki kekuasaan pada wilayah tertentu dalam ikatan suatu negara sehingga terwujud daerah otonom.

Undang-Undang Nomor 22 Tahun 1999 memberikan definisi desentralisasi sebagai penyerahan wewenang Pemerintah kepada Daerah Otonom dalam kerangka Negara Kesatuan Republik Indonesia. Dalam pelaksanaanya, desentralisasi penyelenggaraan pemerintahan di daerah dilaksanakan dengan menyerahkan urusan Pemerintahan kepada Daerah dengan memperhatikan kemampuan, keadaan dan kebutuhan masing-masing daerah untuk mewujudkan otonomi daerah yang nyata, dinamis dan bertanggungjawab.

Berdasarkan Peraturan Pemerintah Republik Indonesia Nomor 84 Tahun 2000 tentang Pedoman Organisasi Perangkat Daerah, Otonomi Daerah adalah kewenangan daerah otonom untuk mengatur dan mengurus kepentingan masyarakat setempat menurut prakarsa sendiri berdasarkan aspirasi masyarakat sesuai dengan peraturan perundangan. Otonomi Daerah merupakan kekuasaan untuk memelihara dan memajukan kepentingan khusus daerah dengan keuangan sendiri, menentukan hukum sendiri, dan berpemerintah sendiri. Daerah otonom adalah kesatuan masyarakat hukum yang mempunyai batas daerah tertentu, berwenang mengatur dan mengurus kepentingan masyarakat setempat menurut prakarsa sendiri berdasarkan aspirasi masyarakat dalam ikatan Negara Kesatuan Repulik Indonesia. Daerah Otonom dapat terwujud dengan dijalankannya asas desentralisasi, karena pemerintah menghendaki agar urusan-urusan pemerintahan dapat diserahkan kepada daerah yang selanjutnya merupakan tanggungjawab daerah sepenuhnya

Hakekat otonomi daerah adalah adanya kewenangan yang lebih besar dalam pengurusan maupun pengelolaan daerah termasuk di dalamnya pengelolaan keuangan. Mardiasmo (2002) memberikan pendapat bahwa dalam era otonomi daerah tidak lagi sekedar menjalankan instruksi dari pusat, tetapi benar-benar mempunyai keleluasaan untuk meningkatkan kreativitas dalam mengembangkan potensi yang selama era otonomi bisa dikatakan terpasung. Pemerintah daerah diharapkan semakin mandiri, mengurangi ketergantungan terhadap pemerintah pusat, bukan hanya terkait dengan pembiayaan, tetapi juga terkait dengan 
(kemampuan) pengelolaan daerah. Terkait dengan hal itu, pemerintah daerah diharapkan semakin mendekatkan diri dalam berbagai kegiatan pelayanan publik guna meningkatkan tingkat kepercayaan publik. Seiring dengan semakin tingginya tingkat kepercayaan, diharapkan tingkat partisipasi (dukungan) publik terhadap pemerintah daerah juga semakin tinggi.

Penekanan Otonomi daerah di Indonesia dititikberatkan pada Daerah Tingkat II. Pelaksanaan otonomi tersebut adalah dengan menyerahkan sebagaian besar urusan oleh Pemerintah dan atau Pemerintah daerah tingkat I kepada Pemerintah daerah Tingkat II secara bertahap dan berkelanjutan. Hal ini didasarkan pada Peraturan Pemerintah Republik Indonesia Nomor 45 Tahun 1992 tentang Penyelenggaraan Otonomi Daerah Dengan Titik Berat Pada Daerah Tingkat II. Dalam Peraturan Pemerintah ini dijabarkan semua urusan yang dapat diserahkan menjadi urusan rumah tangga kabupaten/kota, yaitu :

1. Urusan-urusan yang sifatnya telah membaku di suatu daerah

2. Urusan-urusan yang menyangkut kepentingan langsung dari masyarakat, dan sangat dipengaruhi oleh kondisi lingkungan suatu Daerah

3. Urusan-urusan yang dapat menumbuhkan partisipasi masyarakat atau menurut sifatnya merupakan tanggungjawab masyarakat

4. Urusan-urusan yang dalam pelaksanaannya banyak mempergunakan sumber daya manusia

5. Urusan-urusan yang memberikan penghasilan bagi daerah, dan potensial untuk dikembangkan dalam rangka penggalian sumbersumber pendapatan asli yang baru bagi daerah yang bersangkutan

6. Urusan-urusan yang dalam penyelenggaraannya memerlukan penanganan dan pengambilan keputusan segera.

Sejalan dengan kewenangan tersebut, pemerintah daerah diharapkan lebih mampu menggali sumber-sumber keuangan khususnya untuk memenuhi kebutuhan pembiayaan pemerintahan dan pembangunan didaerahnya melalui Pendapatan Asli Daerah atau PAD (Sidik, 2002). Oleh karenanya penyelenggaraan otonomi daerah akan lebih berdaya guna dan berhasil guna, 
manakala dibarengi dengan kemampuan yang kuat dari daerah dalam mengembangkan atau meningkatkan potensi sumber-sumber keuangan secara optimal. Hal itu berarti, pemerintah daerah dituntut untuk lebih mandiri dalam membiayai kegitan opersional rumah tangganya. Dari beberapa definisi yang telah diuraikan dapat disimpulkan bahwa dalam desentralisasi terjadi proses penyerahan sejumlah kekuasaan/kewenangan dari pemerintah pusat kepada pemerintah daerah yang selanjutnya dijalankan oleh pemerintah daerah secara otonom melalui kelembagaan yang dimiliki sesuai dengan peraturan perundang-undangan yang berlaku. Untuk dapat menjalankan kekuasaan/kewenangan yang dimiliki, pemerintah daerah harus memiliki sumber-sumber daya yang cukup diantaranya adalah sumberdaya keuangan yang memadai

\section{METODE PENELITIAN}

Secara metodologi penelitian ini menggunakan pendekatan penelitian kualitatif yang sering disebut dengan metode naturalistik karena penelitian ini didasari pada kondisi alamiah (natural setting). Pendekatan ini juga merupakan suatu pendekatan yang berorientasi pada fenomen atau gejala yang alamiah. Mengingat orientasinya demikian, maka sifatnya mendasar pada naturalisasi atau bersifat kealamian, serta tidak bisa dilakukan di laboratorium, melainkan di lapangan. Dalam paradigma penelitian ini realitas dipandang sebagai sesuatu yang holistik, komplek, dinamis dan penuh makna yang disebut dengan paradigma postpositivisme anonimnya ialah positivisme yang mengembangkan metode kuantitatif. Sugyono (2014) memberikan penekanan pada objek yang diteliti merupakan objek alamiah, (sebagai lawannya adalah eksperimen) dimena peneliti adalah sebagai instrumen kunci, teknik pengumpulan data dilakukan secara triangulasi (gabungan), analisis data bersifat induktif dan hasil penelitian kualitatif lebih menekankan pada makna daripada generasilisasi.

\section{HASIL DAN PEMBAHASAN}

\section{Uraian Umum Gampong Ulee Pulo}

Gampong Ulee Pulo merupakan salah satu desa di Kabupaten Aceh Utara yang berada di Kecamatan Dewantara. Bagian barat bersebelahan dengan Desa 44 
Ulee Releung, sebelah Selatan dengan Desa Releut timur, wilayah Barat bersebelahan dengan Desa Paloh Lada dan Bangka, sedangkan wilayah tenggara bersebelahan dengan Desa Bangka. Desa ini termasuk salah satu desa yang memiliki keuntungan geograifis, dimana keberadaan desa ini tidak jauh (hanya sekitar 1 sampai 2 KM) dengan pusat industri PT. Pupuk Iskandar Muda dan pusat kantor kantor administrasi sekaligus pusat perbelanjaan Keude Krueng Geukuh.

Tabel 1: Jumlah Penduduk Desa Ulee Pulo

\begin{tabular}{|c|c|c|c|c|c|}
\hline Tahun & $\mathbf{2 0 1 2}$ & $\mathbf{2 0 1 3}$ & $\mathbf{2 0 1 4}$ & $\mathbf{2 0 1 5}$ & $\mathbf{2 0 1 6}$ \\
\hline $\begin{array}{c}\text { Jumlah } \\
\text { Penduduk }\end{array}$ & 1.938 & 2.120 & 2.073 & 2.098 & 2.140 \\
\hline
\end{tabular}

Sumber, Dewantara dalam angka, 2017

Berdasarkan tabel di atas dapat dipahami bahwa angka pertumbuhan penduduk di Gampong Ulee Pulo cenderung stabil, yaitu cendrung naik turun. Data terakhir yang didapatkan bahwa jumlah penduduk sebesar 2.140 jiwa

Tabel 2: Jumlah Penduduk Berdasarkan Jenis Kelami

\begin{tabular}{|c|c|}
\hline Jenis kelamin & Jumlah penduduk \\
\hline Laki & 1.069 \\
\hline Perempuan & 1.071 \\
\hline
\end{tabular}

Sumber: Dewantara dalam Angka, 2017

Tabel: 3 Jumlah penduduk berdasarkan pada Pekerjaan

\begin{tabular}{|l|l|l|l|l|}
\hline Pertanian & Perindustrian & Perdagangan & Transportasi & Jasa dan lainnya \\
\hline 69 & 343 & 36 & 72 & 29 \\
\hline \multicolumn{4}{|c}{ Sumber, Dewantara dalam Angka, 2017 } \\
\hline
\end{tabular}

Data di atas memperlihatkan bahwa mayoritas masyarakat Gampong Ulee Pulo bekerja sebagai buruh pada sektor perindustrian. Industrri-industri rumahan telah menopang kehidupan keluarga masyarakat Gampong Ulee Pulo. Industri yang paling banyak ditemukan ialah industri pengelolaan batu bata dalam bentuk pengelolaan bata basah, dan pembakaran. Pertumbuhan indusstri batu bata ini juga 
mendorong untuk bertumbuhnya jasa trasportasi. Industri ini termasuk industri yang memiliki mobilitas yang tinggi.

Untuk mendapatkan batu bata jadi, terlebih dahulu pengusaha mendatangkan tanah yang dipasok dari luar Desa, kemudian batu bata yang sudah dicetak (masih dalam keadaan basah) diangkut ke tempat pembakaran (panglong: dapu bata), selesai dibakar selama 3 sampai 4 hari bata kemudian diangkut menggunakan kendaraan bak terbuka kepada konsumen. Adanya mobilitas ini mendorong untuk tumbuh dan berkembangnya jasa transportasi yang umumnya juga dimiliki oleh masyarakat setempat.

Secara geografis, Gampong ini tidak memiliki lahan pertanian yang memadai untuk melakukan cocok tanam. Lahan persawahan tidak luas, dan tidak memiliki saluran irigasi. Masyarakat yang ingin bersawah biasanya ke desa-desa tetangga yang memiliki kawasan persawahan yang luas dengan infrastruktur irigasi yang memadai. Seperti di Gampong Releut Barat dan Releut Timur. Sedangkan di Gampong Ulee Pulo area persawahan umumnya adalah sawah dengan tadah hujan. Mereka bekerja sekali atau dua kali dalam setahun.

Masyarakat Ulee Pulo yang bekerja pada sektor pertanian ialah menanam tanaman muda seperti cabai, sayuran, ubi-ubian yang tidak memerlukan lahan luas. mereka memanfaatkan pekerangan dan lahan kosong di belakang rumah. Desa ini tidak memiliki industri pertanian yang besar, layaknya desa-desa yang berada di pedalaman. Strutkru tanah yang tandus dan sebagai berkarang tidak begitu menguntungkan bagi masyarakt setempat jika mengandalkan pada sektor pertanian seutuhnya

Sedangkan usaha (jasa lainnya) ialah masyarakat yang bekerja sebagai pedagang. Karena desa ini berada pada daerah lintasan Banda Aceh - Medan, banyak warga yang membuka usaha perdagangan di pusat keramaian yang terletak di Dusun III. 


\section{Gambaran Usaha Batu Bata}

\section{Gambar I: Dapur pencetakan batau bata basah}

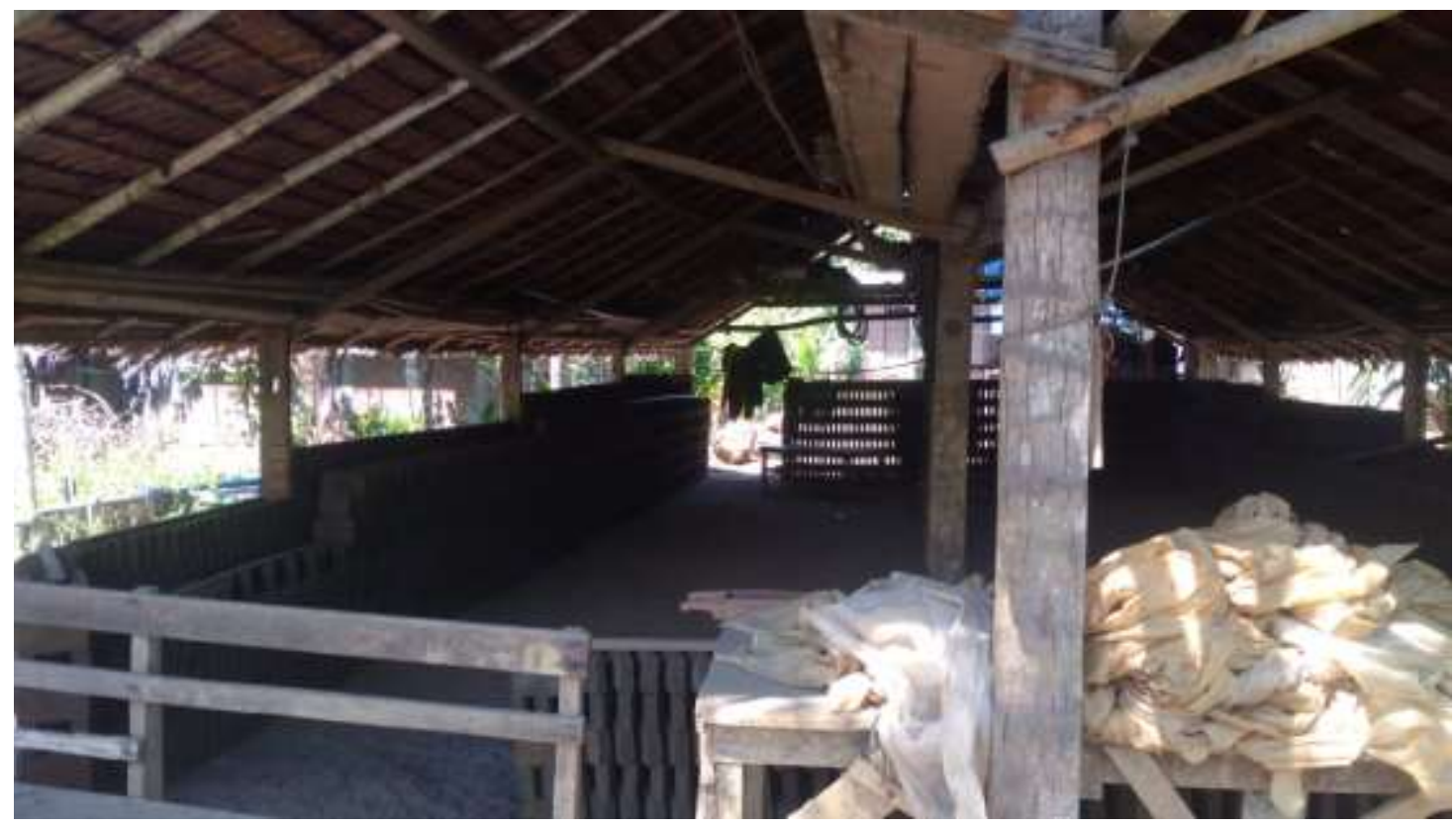

Sumber: dokumentasi milik pribadi.

Keteranagang gambar: dapur batu bata ini milik Nur Aini yang terletak di Dusun I Gampong Ulee Pulo. Dapur pencetakan ini dapat menampung ribuan bata basah yang dikerjakan oleh keluarga. Pekerja biasanya terdiri dari anak famili.

Proses produski batu bata memiliki rangkaian kegiatan yang panjang, memiliki pembagian kerja yang jelas. Mislanya pekerjaan mana yang mesti dilakukan oleh perempuan dan laki-lali atau pekerjaan yang bisa dilakukan oleh kedua jenis gender ini. Proses pembuatan batu bata pertama kali dengan menghancurkan tanah dengan terlebih dahulu dibasahi agar tanah nantinya mudah dimasukkan ke dalam cetakan dan agar strutkur bata yang dicetak lebih padat. Proses ini dalam bahasa Aceh disebut dengan (lhoeh) yang bisa dilakukan dengan menggunakan kaki dengan cara diinjak-injak, menggunakan hewan seperti kerbau atau sapi dan bisa juga menggunakan mesin traktor. Saat ini masyarakat Ulee Pulo umumnya menggunakan mesin traktor dengan sistem sewa atau dimiliki sendiri. pekerjaan ini umumnya dilakukan oleh laki-laki, karena berat dan susah terutama jika menggunakan mesin traktor dan menggunakan hewan ternak. 
Tanah yang sudah dihancurkan kemudian diangkut ke dalam gudang pencetakan (sal bata) yang letaknya bersebelahan. Mereka yang bekerja mencetak bata adalah perempuan dari berbagai usia dan status. Pekerjaan ini relatif mudah dan tidak membutuhkan tenaga yang begitu berat ketimbang pekerjaan lainnya dalam memproduksi batu bata. Mereka yang bekerja di sal bata diupah sesuai dengan jumlah cetakan bata yang dihasilkannya. Untuk satu cetakan upah yang diterima 50 rupiah, jika banyak cetakan yang diselesaikan banyak pula yang hasil yang didapat. Dalam satu sal bata melibatkan 3-5 pekerja perempuan dan bisa lebih sesuai dengan ukuran dan target bata yang harus diselesaikan. Karena pekerjaan ini relatif mudah dan tidak membutuhkan kemampuan khusus banyak pekerja hanya untuk mendapatkan penghasilan tambahan, bukan sebagai penghasilan utama. Sebagian diantara pekerja juga masih berstatus mahasiswa diantaranya ialah Fitrianti mahasiswi Fakultas Ilmu Sosial dan Ilmu Politik Universitas Malikussaleh.

Fitrianti sudah bekerja sebagai pencetak batu sejak dua tahun lalu hingga sampai saat ini, pekerjaan ini ia lakukan di sela-sela kesibukan kuliah dan ketika libur semester. Terlebih saat ini ia tinggal menyelesaikan tugas akhir sebagai mahasiswa Antropologi sehingga memiliki waktu luang yang relatif lebih banyak ketimbang semester-semester sebelumnya.

Dalam sehari ia bisa mencetak 500 batu bata dengan jam kerja dari jam 08 pagi sampai dengan jam 13.00 uang yang dihasilkan rata-rata 25.000 s.d 30.00 rupiah perhari.

"sangat tergantung dari berapa banyak bata yang mampu saya cetak, kalau banyak yang saya cetak, uang yang saya dapatkan juga banyak. Pokoknya semua tergantung dari hasil cetakan. Uangnya sendiri bisa diambil langsung setelah kerja, atau seminggu sekali boleh juga sebulan sekali. Tergantung toke juga, kalau dia punya uang ketika hari itu saya meminta uangnya langsung."

Fitriyanti biasanya bekerja di sal bata miliki Bibinya, tapi saat ini ia dan bibinya sedang bekerja di sal bata milik orang lain yang sedikit lebih jauh dari rumahnya, sedangkan milik bibinya tepat berada di sebelah rumah. Bibinya sudah lebih tiga bulan tidak lagi mencetak bata, bibinya tidak memiliki modal untuk 
membeli tanah. Dalam satu truck empat kodi tanah untuk batu bata biasa dijual hanya 400.000 rupiah, saat ini sudah 500.000 ribu rupiah. Tidak tersedianya modal usaha ini memaksa bibinya untuk bekerja di sal bata milik orang lain.

Kepemilikan modal memang menjadi persoalan utama pengusaha bata, harga batu bata yang tidak stabil dan sering sekali harganya tidak menguntungkan pelaku usaha membuat mereka enggan untuk melanjutkan usahanya secara berkesinambungan.

Tahapan selanjutnya setelah bata dicetak ialah mengangkutnya ke tempat pembakaran (panglong). Biaya pengangkutan tidak dibebani kepada pencetak bata basah, pemilik panglong biasanya yang menanggung seluruh biaya transportasi dan biaya angkut bata basah. Pencetak bata basah akan dibayar oleh pemilik panglong sesaat bata basah tersebut diangkut dengan sitem pembayaran cash maupun pembayaran ketika batu bata yang sudah dibakar laku. Distribusi/pengangkutan bata basah ke lokasi pembakaran secara keseluruhan dikerjakan oleh laki-laki menggunakan kendaraan roda empat bak terbuka.

Bata yang sudah diangkut kemudian dimasukkan ke dalam panglong pembakaran untuk dikeringkan dalam kurun waktu satu minggu. Bata yang basah kemudian dikeluarkan ketika sudah berwarna kemerah-merahan. Proses pembakaran dilakukan oleh laki-laki, kecuali pemindahan dari dalam kendaraan pengangkutan ke dalam panglong yang juga bisa dilakukan oleh perempuan. Sedangkan memasukkan kayu, menjaga api agar selalu hidup dalam besaran yang normal pengecekan secara rutin selama 24 jam dilakukan oleh laki-laki.

Untuk proses pembakaran batu bata membutuhkan waktu 4 sampai dengan satu minggu untuk mendapatkan batu yang sudah siap dipasarkan. Bahan bakar berupa kayu kering dari pohon karet yang ditatangkan dari beberapa daerah seperti Aceh Timur maupun pedalaman Aceh Utara.

Pekerjaan terakhir pemindahan dari dalam panglong pembakaran ke dalam truck pengangkutan untuk dihantarkan ke pelanggan masing-masing. Pekerjaan ini terlihat unik dan menarik. Meskipun pekerjaannya cukup keras dan melelahkan, banyak perempuan yang terlibat. Mereka secara bersamaan memindahkan batu bata dan berbaur bersama laki-laki dalam segala kondisi. Ketika proses pemuatan 
batu bata selesai mereka akan mendapatkan upah sesuai dengan jumlah batu bata yang diangkut ke dalam trusk

Secara keseceluruhan pengerjaan batu bata secara keseluruhan dilakukan dengan cara-cara tradisional, manual dan menggunakan peralatan-peratalan kompensional. Sentuhan mesin apalagi digital tidak akan ditemukan, bahkan atap panglongnya sendiri secara umum atapnya terbuat dari daun rumbia kering yang mudah terbakar.

Minimnya penggunaan peralatan modern dalam proses pembuatan batu menjadikan biaya produksi cukup mahal dan membutuhkan waktu yang relatif lama. Modernisasi pembuatan batu bata sulit diterima bagi pelaku usaha batu bata, dikarenakan konsumen lebih memilih batu bata yang dikerjakan secara manuali. Penggunaan mesin pemotong dan pemadat umpanya, menurut beberapa informan dahulu ada beberapa pengusaha yang menggunakan mesin tersebut, akan tetapi pemasaran produk sangat sulit.

"dulu pernah ada di sini (Ulee Pulo) yang menggunakan mesin pemadat, tapi tidak laku, susah mendapatkan pelanggan” Ujar Haji Madi.

Haji Madi (51) sendiri merupakan pengusaha batu bata yang memiliki belasan panglong batu bata yang kesemuanya berada di Gampong Ulee Pulo. Ia memulai usahanya sejak masih remaja dan berawal dari sebagai pekerja lepas pada salah satu dapur bata miliki keluarga. Saat ini ia memiliki puluhan karyawan yang bekerja pada dapur batanya.

\section{Kemiskinan Pengusaha Batu Bata}

Menarik untuk dipahami mengapa mereka (pelaku usaha batu bata) menghadapi persoalan kemiskinan. Padahal mereka memiliki perkerjaan, berpenghasilan cukup, berada pada lokasi usaha yang strategis, berdasarkan letak geografi mereka berada di kawasan berdekatan dengan kota kecamatan, kawasan industri dan berada di lintasan jalan raya. Bukankah kesemua hal tersebut mampu meningkatkan derajat hidup mereka dan mampu mengeluarkan mereka dari kemiskinan. 
Ditambah lagi dengan adanya datan otnonomi khusus yang dimiliki oleh Aceh secara keseluruhan dengan jumlah yang fantastis. Apakah dana tersebut tidak menyentuh para pekerja dan pengusaha batu bata secara langsung?

Pertanyaan-pertanyaan di atas menjadi fokus dasar dari penelitian ini. Peneliti melihat persoalan kemiskinan yang dihadapi oleh pelaku usaha batu bata di desa Ulee Pulo merupakan persoalan yang kompleks, tapi tidak begitu rumit untuk menemukan jalan keluarnya ketimbang permasalahan kemiskinan yang dihadapi oleh masyarakat miskin yang tinggal di wilayah pedesaan dan di kawasan terpencil yang memiliki jarak yang jauh dengan pusat pemerintahan

Dalam arti proper kemiskinan dipahami sebagai keadaan kekurangan uang dan barang untuk menjamin kelangsungan hidup. Dalam arti luas, kemiskinan merupakan suatu fenomena multi face atau multidimensional. Chambers (dalam Nasikun) mengatakan bahwa kemiskinan adalah suatu integrated concept yang memiliki lima dimensi, yaitu:

1) kemiskinan (proper),

2) ketidakberdayaan (powerless),

3) kerentanan menghadapi situasi darurat (state ofemergency),

4) ketergantungan (dependence), dan

5) keterasingan (isolation) baik secara geografis maupun sosiologis.

Hidup dalam kemiskinan bukan hanya hidup dalam kekurangan uang dan tingkat pendapatan rendah, tetapi juga banyak hal lain, seperti: tingkat kesehatan, pendidikan rendah, perlakuan tidak adil dalam hukum, kerentanan terhadap ancaman tindak kriminal, ketidakberdayaan menghadapi kekuasaan, dan ketidakberdayaan dalam menentukan jalan hidupnya sendiri. Kemiskinan dapat dibagi dalam empat bentuk

a) Kemiskinan absolut: bila pendapatannya di bawah garis kemiskinan atau tidak cukup untuk memenuhi pangan, sandang, kesehatan, perumahan, dan pendidikan yang diperlukan untuk bisa hidup dan bekerja.

b) Kemiskinan relatif: kondisi miskin karena pengaruh kebijakan pembangunan yang belum menjangkau seluruh masyarakat, sehingga menyebabkan ketimpangan pada pendapatan. 
c) Kemiskinan kultural: mengacu pada persoalan sikap seseorang atau masyarakat yang disebabkan oleh faktor budaya, seperti tidak mau berusaha memperbaiki tingkat kehidupan, malas, pemboros, tidak kreatif meskipun ada bantuan dari pihak luar.

d) Kemiskinan struktural: situasi miskin yang disebabkan karena rendahnya akses terhadap sumber daya yang terjadi dalam suatu sistem sosial budaya dan sosial politik yang tidak mendukung pembebasan kemiskinan, tetapi seringkali menyebabkan suburnya kemiskinan.

Kemiskinan pada pelaku industri batu bata dapat dikategori sebagai kemiskkinan yang diakibatkan oleh kebijakan yang tidka memihak kepada mereka. Kebijakan pembangunan baik pemerintah daerah, provinisi maupun kebijakan nasional tidak pernah menyentuh pelaku industri batu bata secara langsung. Seperti pendampingan usaha, mendorong untuk dilakukannya adaptasi terhadap terknologi-teknologi pengelolaan batu bata, memberikan jaminan (asuransi) jika mereka gagal dalam mendapatan pasar penjualan, memberikan kemudahan akses untuk mendapatkan modal usaha.

Sama halnya dengan dana otonomi khusus yang dimiliki oleh Aceh juga tidak kebijakannya tidak menyentuh pelaku industri batu bata ini. Melalui wawancara yang peneliti lakukan, baik aparatur desa maupun pelaku usaha tidak pernah mendapatkan bantuan modal dalam bentuk apapun melalui dana otonomi khusus dari pemerintah pemerintah provinsi Aceh.

Kebijakan ini menjadikan pengusaha batu bertambah miskin dan semakin sulit untuk keluar dari garis kemiskinan. Salah satu informan Muhammad Reza yang sudah tidak lagi menjalankan usahanya, sebab tidak ada lagi modal menjelaskan bahwa mereka seakan bekerja tanpa ada sedikitpun intervensi dari pemerintah.

"tidak tau pasti mengapa kami tidak dipandang oleh negara (pemerintah). Apakah usaha ini tidak dianggap penting? Padahal usaha (batu bata) telah mampu menghidupkan banyak ekonomi rumah tangga dan menyekolahkan anak-anak. Anak-anak mudah seperti kami hampirsemua bekerja di batu bata" 
Kebijakan pembangunan yang tidak menyasar kelompok industri batu bata memberikan dampak serius pada ketimpangan pembangunan di tengah masyarakat. Upah yang minim diterima oleh pekerja (baik pemotong bata basah, pengangkut, maupun yang membakara) tidak seimbang dengan pendapatan yang dihasilkan oleh pengusaha batu bata. Kesenjangan pendapatan ini menimbulkan kesenjangan seirus pada masyarakat. Pekerja tetap menjadi miskin, sedangkan pemilik modal menikmati kekayaan dari hasil penjualannya.

Kebijakan strategis pada dasarnya sangat diperlukan untuk memahami persoalan ini. Yaitu kebijakan sosial yang dapat melindungi kelas pekerja dari berbagai ancaman, bahkan ancaman jika pada suatu saat mereka harus berhenti dari pekerjaannya. Diantaranya ialah negara harus mampu menjamin keselamatan mereka dalam bekerja melalui jaminin sosial ketenaga kerjaan. Jadikan mereka sebagai pekerja yang terlindungi

Temuan penelitian ini memperlihatkan bahwa seluruh masyarakat yang bekerja pada industri batu bata di Gampong Ulee Pulo tidak terdaftar sebagai anggota Badan Penyelenggara Jaminan Sosial (BPJS) Ketenaga Kerjaan. Tidak ada yang dapat menjamin keselamatan dan keberlangsungan mereka dalam melakukan pekerjaannya sehari-hari.

Gambaran kemiskinan pada pelaku industri batu bata dapat dilihat pada skema berikut:

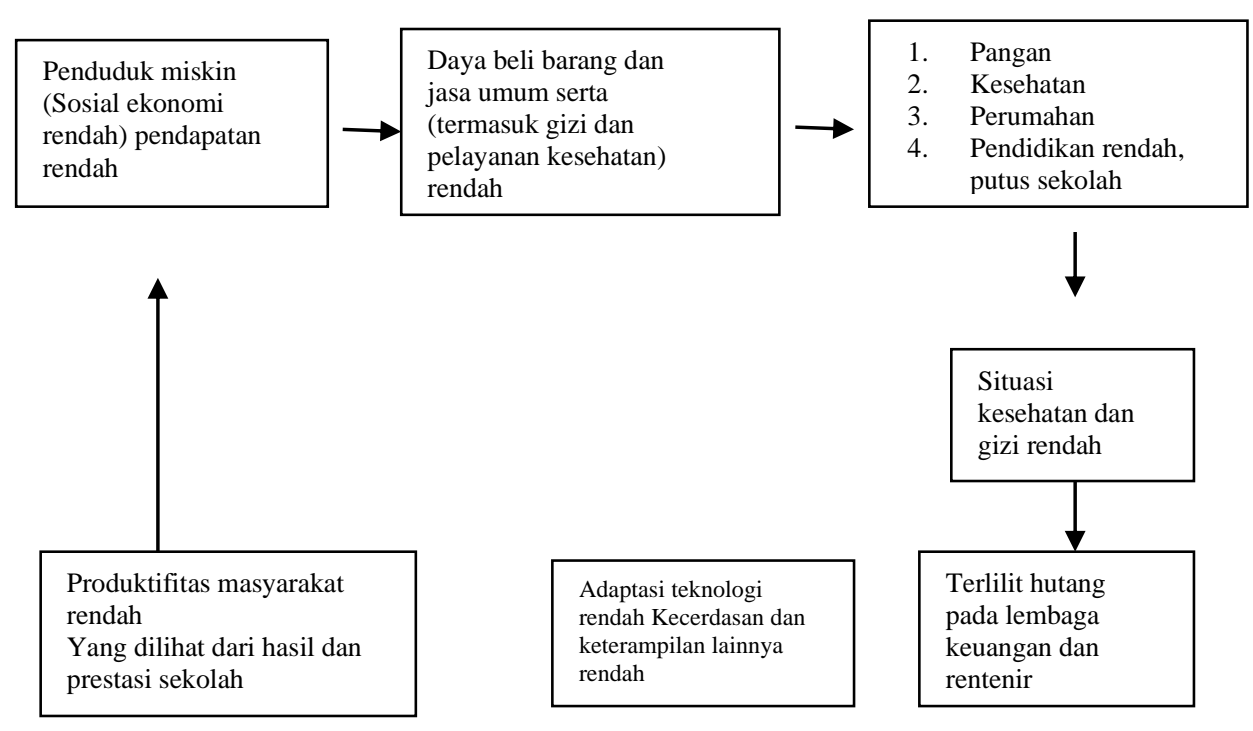


Kemiskinan pada pekerja industri batu bata bata dapat dicirikan sebagai beriktu:

1. rata-rata tidak mempunyai faktor produksi sendiri seperti tanah, modal, peralatan kerja, dan keterampilan,

2. mempunyai tingkat pendidikan yang rendah,

3. kebanyakan bekerja atau berusaha sendiri dan bersifat usaha kecil (sektor informal), setengah menganggur atau menganggur (tidak bekerja),

4. kebanyakan berada di pedesaan atau daerah tertentu perkotaan (slum area), dan

5. kurangnya kesempatan untuk memperoleh (dalam jumlah yang cukup): bahan kebutuhan pokok, pakaian, perumahan, fasilitas kesehatan, air minum, pendidikan, angkutan, fasilitas komunikasi, dan kesejahteraan sosial lainnya.

Seperti yang sudah disinggung sebelumnya bahwa untuk membuka usaha industri ini memerlukan modal yang tidak sedikit, baik dari pembangunan infrastrukturnya (dapur pengolahan dan dapur cetak), modal kerja (tanah dan kayu). Maka banyak warga memilih untuk menjadi pekerja ketimbang membuka produksinya sendiri. mereka pada akhirnya menjadi buruh pada industri ini. Perempuan umumnya menjadi buruh pemotong bata basah dengan rata-rata penghasilan 35.000 hingga 50 ribu rupiah perharinya. Sedangkan laki-laki bekerja pada buruh angkut dan buruh pembakar bata dengan penghasilan 50 ribu sampai 100 ribu rupiah perharinya. Tergantung dari produktifitas mereka.

Masalah penyertaan modal usaha menjadi persoalan utama pelaku usaha batu bata. Pelaku usaha tidak memiliki modal yang mupuni agar usaha mereka berkelanjutan. Untuk satu kali produksi dibutuhkan modal 3 sampai dengan 5 juta rupiah. Dampak yang lebih buruk dihadapi oleh Muhammad Reza, usaha pembakaran batu bata yang telah dijalaninya bersama keluarga harus tutup karena tidak memiliki modal usaha lanjutan. Pembangunan dapur pembakar batu bata awal mulanya dibangun menggunakan dana pinjaman dari salah satu bank. Hasil usahanya digunakan untuk menutupi cicilan hutang bank yang dibayar tiap 
bulannya. Setelah beberapa tahun usaha tersebut berjalan Muhammad Reza terpakasa tidak lagi melanjutkan usahanya.

Faktor lain penyebab rendahnya produktivitas ekonomi kelompok miskin dan rentan di wilayah KTI adalah belum optimalnya skala usaha dan keterhubungan dengan pasar yang lebih luas. Di satu sisi, masyarakat miskin dan rentan terlibat dalam sektor ekonomi yang produktivitasnya rendah serta komoditas yang belum terhubung dengan pasar yang lebih luas. Hal ini disebabkan oleh belum optimalnya pengembangan skema kerjasama antara swasta dan kelompok masyarakat serta adopsi teknologi dan inovasi yang masih rendah. Akumulasi dari kondisi tersebut membuat sektor ekonomi produktif di wilayah KTI terjebak pada skema business as usual dan berkutat pada sektor-sektor usaha yang sudah jenuh.

Bekerja sebagai buruh pemotong bata basah maupun pengangkut batu bata ke dalam truk pengangkutan tidak mencukupi untuk menutupi kebutuhan masyarakat sehari-hari. Penghasilan yang didapatkan dari dua jenis pekerjaan tersebut rata-rata hanya Rp. 50.000 bahkan terkadang tidak sampai. Terutrama pada pekerja pemotong bata yang seharinya hanya mampu memotong dengan maksimal 700 keping bata dikali dengan harga perkepingnya $\mathrm{Rp} 50=\mathrm{Rp} .35 .000$

\section{Pentingnya Skema Kerjasama}

Penelitian ini menemukan bahwa usaha batu bata masuk dalam kategori usaha-usaha yang mudah jenuh. Artinya banyak pengusaha batu bata yang mengalihkan usahanya pada usaha lainnya jika dianggap tidak lagi mengungtungkan. Keberlanjutan usaha sangat tergantung pada permintaan pasar, pada musim sepi pembeli usaha ini akan tutup dan kembali bergeliat jika permintaan meningkat. Kondisi ini sangat berdampak pada sistem ketenaga kerjaan dan pendapatan rutin anggota keluarga. Tidak jarang ditemukan banyak rumah produksi batu bata yang berhenti bukan dikarenakan terbatasnya bahan baku yang tersedia. Melainkan pengusaha yang tidak memiliki modal lanjutan akibat berhentinya produksi pada priode tertentu. 
Permaslahan ini bermuara pada komoditas yang belum terhubung dengan pasar yang lebih luas, pengembangan skema kerjasama antara swasta dan kelompok masyarakat serta adopsi teknologi dan inovasi yang masih rendah. Pasar utama dari batu bata ini ialah pasar domestik yang umumnya berasal dari Kota Lhokseumawe dan Kabupaten Aceh Utara. Sedangkan permintaan dari luar dua daerah ini sangat sedikit sekali. Pengusahaan tidak mampu menembus pasar luas, karena usaha yang sama juga hampir ditemukan di setiap wilayah di Aceh. Kabupaten Bireun misalnya, daerah ini memiliki beberapa tempat yang jumlah produksi batu batanya lebih besar ketimbang wilayah Aceh Utara.

Ekspansi pasar ke luar wilayah mungkin saja terjadi jika pasokan dari wilayah daerah masing-masing tidak mencukupi untuk kebutuhan domestik. Celah inilah yang kemudian membuka peluang bagi pengusaha batu bata untuk menjamah pasar luas. Namun, pendekatan seperti ini sulit untuk dijangkau. Pengusaha batu bata tidak memiliki kemampuan untuk memprediksi pasar secar komperhensif. Jaringan bisinis selama ini hanya terjalin pada komunikasikomunikasi yang bersifat personal dan terbatas.

Selanjutnya, pengembangan skema kerjassama antara swasta dan kemlompok masyarakat. Swasta berperan penting dalam upaya untuk melanjutkan industi ini, sehingga industri ini tidak tergantung pada projek-projek pemerintah yang bertumpu pada priode-priode tertentu. Pada saat musim proyek industri ini kewalahan dalam mencukupi kebutuhan pasar, banyak permintaan yang tidak terpenuhi. sedangkan pada musim sepi proyek mereka berhenti produksi. Swasta berperan dalam menutupi kekosongan ini

Upaya penghubungan kerjasama ini tentu tidak dapat dilakukan melalui pengusaha secara individu, asosiasi pengusaha batu batu diperlukan untuk menjangkau pasar secara terbuka atau melalui sistem pengendalian koperasi yang dibangun secara bersama. Sistem monopoli seperti pada satu sisi menguntungkan pengusaha agar usaha tertap berjalan dengan jangkauan pasar yang luas. sisi lainnya kesiapan sumber daya manusia mesti mupuni. Pangusaha tidak hanya dituntut untuk mengolah bahan baku menjadi bahan jadi yang siap pakai mereka mesti dipersiapkan untuk memahami industri batu bata sebagai industri strategis. 
Sejauh ini pengusaha batu bata belum terhubung satu dengan lainnya, jaringan sesama pengusaha masih sebatas pada jaringan persahabatan dan kerjsama yang bersifat temporer dan terbatas. Keterbatasan ini dapat dipahami karena memang dalam mekanisme kerjana industri ini dibangun dan dikelola dengan cara-cara trdisional, usaha dibangun atas dasar kekeluaragaan yang berbasis pada home industry hingga penjualan juga dilakukan tanpa melalui sistem penjualan yang berhubungan dengan teknologi seperti yang dijelaskan pada ulasan sebelumnya.

Persoalan utama selanjutnya ialah adaptasi teknologi yang belum seutuhnya diterima dengan baik sebagai konsekuensi atas industrialisasi. Caracara pengelolaan tradisional masih menjadi andalan utama industri ini, dari pertama hingga akhir produksi. Lambannya adaptasi teknologi ini disebabkan oleh banyak faktor yang bukan saja bertumpu pada keengganan pelaku untuk mengadopsinya. Persepesi pasar juga sangat mempengaruhi

Peralihan dari pemotongan dan pengepresan (pemadatan) bata basah secara manual menjadi tenaga mesin misalnya, pengusaha menyadari penggunaan mesin dapat memotong ongkos (upah) pekerja hingga beberapa persen. Namun persepsi pasar terhadap bata yang diolah menggunakan mesin memiliki kualitas lebih rendah ketimbang batu bata yang diolah secara manual. Persepsi ini telah diwaiskan secara terun temurun dan menyebar dari mulut ke mulut warga. Hingga akhirnya mereka (pengusaha bata) tetap menggunakan medium tradisional.

Sulitnya mengadopsi perubahan pada struktur industri ini memerlukan campur tangan pihak luar yang mampu menjelaskan kepada publik bukan hanya sebatas pada kecanggihan dan kelebih peralatan. Masyarakat (konsumen dan produsen) mesti memahami bahwa industrialisasi memerlukan alternatif lain beruapa peralatan guna memudahkan pekerjaan. Proses inilah yang sering dikenal dengan divusi inovasi, yaitu bagaimana sebuah ide dan teknologi baru tersebar dalam sebuah kebudayaan.

Rogers (1983) mendefinisikan difusi sebagai proses dimana suatu inovasi dikomunikasikan melalui saluran tertentu dalam jangka waktu tertentu di antara para anggota suatu sistem sosial (the process by which an innovation is 
communicated through certain channels overtime among the members of a social system). Disamping itu, difusi juga dapat dianggap sebagai suatu jenis perubahan sosial yaitu suatu proses perubahan yang terjadi dalam struktur dan fungsi sistem sosial. Inovasi adalah suatu gagasan, praktek, atau benda yang dianggap/dirasa baru oleh individu atau kelompok masyarakat. Ungkapan dianggap/dirasa baru terhadap suatu ide, praktek atau benda oleh sebagian orang, belum tentu juga pada sebagian yang lain. Kesemuanya tergantung apa yang dirasakan oleh individu atau kelompok terhadap ide, praktek atau benda tersebut.

\section{KESIMPULAN}

Dana otonomi khusus di Aceh tidak memiliki orientasi pembangunan dan perlindungan yang jelas terhadap tenaga kerja informal. Limpahan dana otsus terfokus pada pembangunan infrastruktur tanpa memperhatikan pentingnya perlindungan terhdap pekerja-pekerja pada sektor industri informal yang pada dasarnya industri-industri informal telah berkontribusi pada pembangunan. Banyak masyarakat yang bertopang pada industri informal dengan serapan tenaga kerja yang luas dan banyak. Namun, industri-industri informal yang pada dasarnya juga sebagai industri rumahan kerap gugur di tengah jalan. Pelaku industri ini tidak mendapatkan jaminan langsung dari negara, apalagi yang bersumber dari dana otonomi khusus. Pekerja-pekerja pada sektor ini tidak mendapatkan jaminan sosial, mendapatkan upah yang layan (UMR), dan mereka hidup dalam garis kemiskinan

Diantara pelaku industri pengolahan batu bata di Gampong Ulee Pulo Kecamatan Dewantara Kabupaten Aceh Utara. Desa ini memiliki industri pengolahan batu bata yang sangat ramai. Hampir keseluruhan warganya tergantung pada industri rumahan ini. Persoalan utama yang dihdapi oleh pelaku industri pengolahan batu bata ialah 1) penyertaan modal, 2) adaptasi teknologi yang masih sangat rendah, 3) permintaan pasar yang tidak stabil, dan 4) biaya produksi yang sangat mahal. Masalah tersebut tidak tertangani oleh negara dan cenderung diacuhkan dan berdampak luas bagi keberlangasungan usaha. Banyak pengusaha-pengusaha batu bata yang "gulung tikar" karena tidak memiliki modal 
yang mencukupi. Untuk mendapatkan modal pengusaha mengajukan pinjaman (loan) pada lembaga-lembaga keuangan dan rentenir. Namun, sering kali pinjaman ini berujung petaka. Dengan sistem bunga, banyak pengusaha yang tidak mampu membayar cicilan tidap bulannya. Hasil dari penjualan diharapkan dapat meningkatkan taraf hidup mereka, sebaliknya hutang justru menjerat mereka dan menjerumuskan mereka kepada kemiskinan bekelanjutan hingga hutang selesai 


\section{DAFTAR PUSTAKA}

Askhalani, dkk, Korupsi di Negeri Syariat: Catatan Jaringan GeRAK Aceh, Aceh: GeRAK Aceh, 2009.

Badrudin, Rudi, Ekonomika Otonomi Daerah, Yogyakarta: UPP STIM YKPN. 2012.

Boediono, Ekonomi Makro Edisi Keempat, Yogyakarta: BPFE, 2011.

Boediono, Perekonomian Indonesia, Yogyakarta: BPFE, 1999.

Departemen Keuangan RI, Usulan Formulasi Dana Alokasi Umum Tahun 2002, Jakarta: Indonesia, 2001.

Djohan, D, Desentralisasi Asimetrik di Aceh, Jakarta Jurnal Ilmu Pemerintahan, MIPI,2006.

Djojosoekarto (ed.), dkk, Grand Strategi Penataan Dsaerah 2025: Bunga Rampai Wacana, Jakarta: Kemitraan, 2008.

Hendra, Roy, Determinan Kemiskinan Absolut di Kabupaten/Kota Provinsi Sumatera Utara Tahun 2005-2007, Tesis 2010.

Kaputra, dkk, Dampak Otonomi Daerah di Indonesia, Jakarta: Yayasan Pustaka Obor,2013.

Luthfi, A, Impact of Aceh's Additional Budget From Special Autonomy OilGas Revenue Sharing Fund to Poverty Reduction in Aceh, Aceh: ICAIOS's Journal, 2012.

Mardiasmo (2002). Otonomi dan Manajemen Keuangan Daerah. Jakarta: Andi Publisher

Masyarah, Harry, dkk, Post-Tsunami Aid Effectiveness in Aceh: Proliferation and Coordi-nation In Reconstruction, The Brookings Global Ekonomi and Development Working Paper Series, Washington D.C.: Wolfensohn Center for Development and The Brookings Institute, 2008.

Mollet, Julius Ary, Special Autonomy and Poverty Reduction Programs in Papua: Does it Work?, Papua: Jurnal Universitas Cendrawasih, 2012.

Peraturan Pemerintah Republik Indonesia Nomor 84 Tahun 2000 tentang Pedoman Organisasi Perangkat Daerah, Otonomi Daerah 